\title{
Aestheticism versus Realism? Narcissistic Mania of the Unheeded Soul in Oscar Wilde's The Picture of Dorian Gray
}

\author{
Ali Taghizadeh (corresponding author) \\ Department of English Language and Literature, Faculty of Arts, Razi University, Kermanshah, Iran \\ Mojtaba Jeihouni \\ Department of English Language and Literature, Faculty of Arts, Razi University, Kermanshah, Iran
}

\begin{abstract}
Wilde's complete adherence to aestheticism led him to write beautifully but maybe without any stress on the significance of morality. His only novel The Picture of Dorian Gray reveals his philosophy of aestheticism in both art and life. The standpoint of 'beauty' dominates the novel in a way that almost all of its possible themes are shadowed or directed through the strict filter of aestheticism. However, it seems that this is only a half-truth, as moral and social issues are also revealed with a fastidious precision. Dorian Gray is constantly troubled by the ghosts of conscience, aging, and alienation, and these ordeals force him into the dark dungeon of paranoia. Hence, the common knowledge concerning Wilde's art is a matter of debate, and this scrutiny essays to lay stress on the assumption that this novel is not solely an aesthetic work but a combination of aestheticism and realism. To accomplish this, the present study aims to delve into the inordinate fear and vulnerability of Dorian Gray's character, which is dominantly ruled by the fading beauty of his soul. The paper will put the novel under the scrutiny of the psychological trauma of narcissism to conclude how social alienation brings about Dorian Gray's mental breakdown.
\end{abstract}

Index Terms-Wilde, Dorian Gray, narcissism, mania, society

\section{INTRODUCTION}

Oscar Wilde's masterful art and philosophical intellect place him at a far distance ahead of his peers. Roden (2004) says, he "was not the first to insist on art's autonomy, but he has frequently been seen as championing the idea" (pp. 99100). Wilde believed that artistic beauty should be the basic goal of a literary work while moral pedagogy should not be considered as its primarily significant object. Even if it works for the representation of moral qualities, the presentation of such qualities is to be eclipsed by aesthetic merits. And it is for the achievement of such a thorough aesthetic objective that in the preface to The Picture of Dorian Gray, he reproachfully claims that, "no artist has ethical sympathies. An ethical sympathy in an artist is an unpardonable mannerism of style" (Wilde, 2005, p. 3). If Wilde is right in this claim, art's lack of ethical sympathy is a unique point which renders it an autonomous entity that appeals to no appetitive or other forms of subjective interest. However, Wilde in actuality, as this study is expected to point out, underlines the significance of ethics, and deems it as important as art itself. Therefore, a literal reading of his quotes seems to make him paradoxical and inconsistent.

Wilde's inexpressible ability in questioning the conventions of the English society has brought an unforgettable name out of him in the English Literature. He was an active author both in prose and verse; though, his verse was/is not usually esteemed as high as his prose. His dramas show a brilliant satire of society; his short stories revive a sense of reading; his only novel pictures his aesthetic notion more clearly than his other works. Therefore, it does not sound a surprise to read Bloom's assertion:

We cannot be Wilde, as his genius is beyond us, but we need to be as Wildean as possible in writing about him. A conventional response will fail. Oscar is paradox and needs to be ambushed —-by wily stratagems and (only apparently) lunatic juxtapositions (Watkin, 2010, p. viii).

His revolutionizing and trailblazing attitudes toward art and life are his inseparable qualities, and, through this consideration, it becomes apparent to see him heads and shoulders above his peers. As a matter of fact, he does not deal with the common preoccupations of the day; instead, he goes beyond the constraints of time and place, dealing with the perpetual predicaments so as to immortalize his name. This seems to stand as one of the main reasons he was usually unassimilated by his generation and was under the bitterest reproaches. Nevertheless, the fact did not stop some of his contemporaries and the later generations from treasuring his work. As Roden avers:

Oscar Wilde did everything there is to be done with words. He spoke them, his contemporaries tell us, like no one else. He wrote plays in which the dialogue mirrored his own spoken ability and agility, plays that have remained popular and perpetually performed - even during the years of what everyone at the time, including Wilde, referred to as his "downfall" and disgrace (2004, p. 36). 
His novel The Picture of Dorian Gray reveals an individual's complete submission to the passions of soul, which, however sweet, shackle the protagonist in nostalgia and phobia. Wilde's work, indeed, delineates his picture of life in an era when individuality has its own predetermined implications. A subjection to hedonism and Epicureanism leads Wilde's course in the novel so that he can weaken the pillars of conventions in the Victorian society. A pleasureoriented life pictured at its loftiest measure is not among those accepted norms of the society. Consequently, Dorian Gray's life is led to irresolution and suspense at the end of the novel, as pleasure, even in its moral scope, is not accepted but with notoriety and ignominy.

The paper gives a short introduction on the novel, and then continues with studying Dorian Gray's unconventional attitudes which isolate him from society. The study comes to its concluding point by discussing the dubious identity an individual may arrive at as a consequence.

\section{THE PICTURE OF DORIAN GRAY}

The Picture of Dorian Gray seems to have stabilized the name of Oscar Wilde in the history of the Victorian Novel. Along with Mary Shelley's Frankenstein, Robert Louis Stevenson's Dr. Jekyll and Mr. Hyde, and Bram Stoker's Dracula, The Picture of Dorian Gray is one of the prominent English Horror novels of the $19^{\text {th }}$ century. Upon its appearance as the lead story in Lippincott's Monthly Magazine on the $20^{\text {th }}$ of June 1890 , it received mixed reviews of both acclaim and reproach. Athenaeum wrote:

So much may be said for The Picture of Dorian Gray, but no more, except, perhaps, that the author does not appear to be in earnest. For the rest, the book is unmanly, sickening, vicious (though not exactly what is called 'improper'), and tedious (qtd. in Beckson, 2005, p. 85).

However, one of Wilde's masters found an interesting exemplification of aesthetic philosophy in the book. Walter Pater asserted:

We need only emphasise, the skill, the real subtlety of art, the ease and fluidity withal of one telling a story by word of mouth, with which the consciousness of the supernatural is introduced into, and maintained amid, the elaborately conventional, sophisticated, disabused world Mr. Wilde depicts so cleverly, so mercilessly (Ibid., p. 89).

The latent truth regarding Wilde's novel was that his awareness of literary deficiencies of his day was well pictured in it. Wilde had become cognizant that it was no longer the time of Dickensian realism. And if something was to be achieved that would enhance the import of literature in its own right was a radical departure from the former conventions of writing fiction. Hence, it is not surprising to witness the turbulence the novel made when it was published. It truly bore Wilde's prophecy that it would arouse uproar and become his masterpiece. Mason avers:

Wilde was indeed a true prophet when he foretold that his story would create a sensation. Though it occupied but a hundred pages in a monthly periodical, it was reviewed as fully as any chef d'oeuvre of a leading novelist (2011, p. 5).

Whatever the opinion of his contemporaries, the work shows the brilliance of Wilde's mind; that is to mean, the novel subtly questions the norms and conventions of his society. His novel brings to picture the helpless submission of a young man to whatever is the imposition of the society. It actualizes the assumption that the seemingly different individuals are doomed to experience the strange look of the society, which brings nothing but suffering upon them.

Indeed, the $19^{\text {th }}$ century's apprehension in searching for a device to certify the miseries of human beings unanimously culminated in fiction. From its earliest days, it had become conscious that it was meant to be the voice of the silenced folks, and the appearance of such titans like William Makepeace Thackeray and Charles Dickens proved it. It could be claimed that the main aim of the English fiction in this era was not the realization of artistic sublimity but to show the asperity of life as experienced by the multitude. Later on, with the rise of George Eliot, this notion even got stronger. However, the abrupt ascendancy of aestheticism changed the commonplace attitude. That is, there started to be a stress on the importance of art with its given web of complexities rather than on a devoted portrayal of life. Wilde as the champion of aestheticism advocated the idea more influentially than others. While considering The Picture of Dorian Gray as something away from the realistic traditions of the day, Killleen expounds:

The largely unexplained alteration in Dorian's portrait indicates that Wilde's novel is outside the Victorian realist tradition. Indeed, in his many book reviews, Wilde was not enthusiastic about realism as a mode of writing as it made too great a distinction between reality and fantasy. He was uneasy with the work of realists like George Eliot because he did not believe that their commitment of being true to material life was adequate (2005, p. 83).

This shows that Wilde's supreme ideal was not to be devoted to the factual life but mostly to the spaces of imagination. Wilde believed that the responsibility of a writer lied in creating a work of art mostly free from real life, since, as he believed, art was not a chronicle (as qtd. in Watkin). He asserted:

This is the supreme advantage that fiction holds over fact: it can make things artistically probable, and by force of mere style, compel us to believe. The ordinary novelists, by keeping close to the ordinary incidents of commonplace life, seem to me to abdicate half their power (qtd. in Killeen, p. 83).

Taking the Wildean notion into account, it is believed that The Picture of Dorian Gray is a prefect combination of fact and fiction, life and imagination, certainty and possibility. This only goes to reveal the point that, despite Wilde's unconventional ideas, he promotes a fascination with the diverse possibilities offered by both realism and aestheticism. To put it differently, he does not stop being a realist by remaining an aesthete. He revives the imaginative hunger of expectant readers for innovation by devising (or perfecting) a combination of both artistically and realistically visible. 
An important facet of Wilde's novel is the significance of morality in human world. One could argue that Wilde had faith in morality (something which he has always been accused of not possessing); however, his very peculiar treatment of it necessitates a very peculiar reading of him as well in order to conceive his hidden morality. As it will be discussed later, The Picture of Dorian Gray possesses a unique approach to the weighty import of leading a moral life. Therefore, it seems that the reproach always pointed to Wilde's art is out of place. Gilbert Keith Chesterton contended: "He[Wilde] sometimes pretended that art was more important than morality, but that was mere play-acting. Morality or immorality was more important than art to him and everyone else" (Bloom, 2008, p. 57).

\section{CAPTIVITy OR DeliveranCE? A PREWRITTEN DESTINY}

Living in a society the values and norms of which are inordinately dominant, the typical individual may not readily enough get socially integrated. An individual's mind is influenced by the orthodoxies of his society, for to the health of the person's mentality, these orthodoxies are either helpful prescriptions or fatal resolutions. In a desirable condition, the individual accepts such codes and adapts himself with them, as a result of which, he at least attains a peace of mind. However, when an individual comes to realize that the prevalent values do not suit his mode of thought, he strives to stand against them. This typical attitude is to make him radically different from other citizens who most likely yield to the social norms and values. In one sense or the other, what on the surface appears to be a right to private life for him might actually signify beneath the surface a sentence to exile. Therefore, this kind of conduct would not probably provide the opponent individual with satisfaction, and his life would be a battleground with him being fettered by undying misfortunes.

In The Picture of Dorian Gray we come across such a sense of non-belonging. Dorian Gray's unique appearance definitely distinguishes him from other individuals of his society. In this sense, he is already different from others. Moreover, he is naïve in an unusual way. Hence, his identity is easily shaped by someone who can use words more craftily than others. This someone is Lord Henry Wotton, who, as a master of language, molds Dorian's character the way he desires. His hedonistic ideals lull Dorian into believing that it is pleasure which matters most. Dorian in turn accepts Wotton's ideals, bases his character upon them, and incessantly faces the somber consequences of his resolution. Therefore, as it was mentioned earlier, belonging to the minority of one's community could occasion unpalatable aftermaths. For this reason, Wilde's reader can understand why Dorian's mania of pleasure only aggravates his situation, and why he is gradually pushed to almost total isolation. In this way, Dorian can be seen as the proper embodiment of an imprisoned soul. His peculiar qualities put him in the spotlight, and the society makes ruthless and relentless assessments as to him. Accordingly, his future is set by the monolithic forces of the society, while he is drowned into the devouring slough of narcissism. He is unduly self-involved and beyond reach; he pictures a world with him acting as the center of it. And if he feels menaced from the side of something, he cannot relieve himself of the thought of it by any means. We can observe this self-centered dimension of Dorian's faith via his reaction to the picture Basil Hallward has recently made of him:

"How sad it is!" murmured Dorian Gray with his eyes still fixed upon his own portrait. "How sad it is! I shall grow old, and horrible, and dreadful. But this picture will remain always young. It will never be older than this particular day of June. . . . If it were only the other way! If it were I who was to be always young, and the picture that was to grow old! For that - for that - I would give everything! Yes, there is nothing in the whole world I would not give! I would give my soul for that" (Wilde, pp. 27-28)!

Dorian's fear of the imminent future makes him forget his present state of beauty and youth only because the prevalent atmosphere of his society compels him to keep a blind eye to the blessings he presently has. Thus, he is led to pessimism, doubt, and disillusionment. Ahead of him, he only has two alternatives: either to submit to, or to resist the forces of bewilderment and despondency. As a member of a social minority, he copes with a continuous wave of preoccupations, and has difficulty to decide which move to take. If he decides to be a part of the majority, his mental restlessness might start to cease. But since he belongs to the minority who do not succumb to the exertions of the superior voices, he grants the much-asked-for privilege to the majority to encroach upon his mental security. Simon (2004) argues that, under undesirable circumstances, minorities may adopt themselves with majorities. However, in Wilde's novel we witness Dorian's resistance against the social ideals and standards. A manifestation of his social resistance is that he avoids yielding to unwanted beliefs, and by remaining pleasure-stricken, he invites others to his feast of trepidation and tribulation. In the following speech, if we listen to Dorian closely enough, we will realize how deep his discontent with Sybil's unpleasing performance, which acts against his beautiful ideals, is:

"Yes," he cried, "you have killed my love. You used to stir my imagination. Now you don't even stir my curiosity. You simply produce no effect. I loved you because you were marvelous, because you had genius and intellect, because you realized the dreams of great poets and gave shape and substance to the shadows of art. You have thrown it all away. You are shallow and stupid. My God! how mad I was to love you! What a fool I have been! You are nothing to me now. I will never see you again. I will never think of you. I will never mention your name. You don't know what you were to me, once. Why, once ... Oh, I can't bear to think of it! I wish I had never laid eyes upon you! You have spoiled the romance of my life. How little you can know of love, if you say it mars your art! Without your art, you are nothing. I would have made you famous, splendid, magnificent. The world would have worshipped you, and you would have borne my name. What are you now? A third-rate actress with a pretty face" (Wilde, p. 84). 
Dorian's resolve is not of an ordinary kind. His attachment to earthly vanity brings to light his Faustian destiny. Like Faust, he yields to a pact with evil. To manage an ordinary lifestyle is not included among his alternatives, because he already has it in his mind that his similarities, if any, with other people are few. Thus, he resolves upon taking an unconventional path. But to pass that path, he is fully aware he has to make some sacrifices, the most important of which is his very self. From this time on, the bonds of morality are cut one by one, and he pursues his narcissitic ends without respite. His expectations lead him to such an excess that he is only obsessed to achieve the utmost degrees of pleasure. He turns out to be indifferent to others, and, as an instance, shatters the ideals of Sybil, ushering her to suicide. However, he does not continue remaining the same man. After a struggle with his conscience, he comes to appreciate that earthly pleasures are less than everything. Wilde himself opined on Dorian:

Dorian Gray has not got a cool, calculating, conscienceless character at all. On the contrary, he is extremely impulsive, absurdly romantic, and is haunted all through his life by an exaggerated sense of conscience which mars his pleasures for him and warns him that youth and enjoyment are not everything in the world. It is finally to get rid of the conscience that had dogged his steps from year to year that he destroys the picture; and thus in his attempt to kill conscience Dorian Gray kills himself (qtd. in Watkin, p. 123).

What one becomes is in close connection with what the society desires. The intermingling characteristic of human societies poses an obligation on the (re)actions of the individual. This notion seems to be applicable in all human relations. In the light of this notion, Dorian's mental disturbances are easily perceived. The immoderate attention and, at the same time, the unreasonable negligence of his society gradually oblige him to be excessively apathetic concerning the judgments made upon him. He is seen as a handsome and naïve guy, and everybody deems himself responsible for the formation of his character. Duplicitous men enter the scene and teach him all the possible immoralities for his doom. Now, those who supposedly are vice reformers take a conscious step backward, and, after the imminent disaster, such people condemn him for his committed, yet unconscious, crimes. Therefore, even the dim possibility of breathing a new life into his self is ruled out, since one normally expects others to view him the way he views himself, and when they do not do so, he regards his life futile and unavailing. Such dichotomy obscures his reasoning power, and all the ensuing steps will be based on the impulses of the moment. Jenkins (2008) maintains:

Some distinction between the internal and the external is unavoidable. Not everything going on in our heads and hearts is obvious to others, nor is there always harmony between how we see ourselves and how others see us (or how we imagine they do) (p. 50).

Dorian is indeed a victim of the ferocious conventions of his society. Society, as the mother to all citizens, is expected to breed her children in the right ways. However, the ignorance of this mother puts an end to their motives of enlightenment and purity. Dorian Gray is one of the hapless victims of the ignorant mother. His beauty and exceptional character are naturally in need of a caring affection. And while his expectations are there, he also broods over other alternatives. He realizes that he can lead an indifferent life with the least care about the ethics of society. And when his expectations are not gratified by the society, his temptation is reinforced even more squarely. For, in his quest of finding his lost identity, he yearns to have self-esteem by the power of which he might be able to regain his status among others. Schwartz-Salant believes that a narcissist suffers from such symptoms as "anxiety, depression and paranoid tendencies," and adds, "but these are strictly secondary compared to the person's major complaint, which is a lack of identity and self-esteem" (1982, p. 9). To make everything worse, the presence of a strong agent of dubious morality in his life like Lord Henry Wotton paves an ugly path for him to suffer through. In this sense, The Picture of Dorian Gray is a bridge between imagination and reality. Mendelssohn (2007) explicates on the notion and discusses the influence of Lord Henry on the changes happening in the novel:

The Picture of Dorian Gray offers a total connection between art and life, between what happens to the painting, and what happens to Dorian. These alterations are not brought about by the painter, but by the critic, Lord Henry, the greatest agent of change in the novel (p. 153).

He witnesses the beauty of Dorian and persuades him to think of nothing but pleasure. Dorian clings to this thought and becomes the perfect quintessence of an amoral man. This mental rejection forces him to suffer greatly under "the burden of his passions and his sins" (Wilde, p. 87), and what remains of him is a person who has reached the end of the line. His fine appearance among others does not conceal his self-hatred or his paranoiac mentality. He himself may essay to appear what he is not by pretending an artificial self; yet, at the end of the day he is found out. While declaring that narcissists unreasonably depend on others for maintaining their self-esteem, Rhodewalt and Morf (2005) extrapolate, "narcissistic adults possess the appearance of a grandiose self-concept and invulnerability on the outside but harbor feelings of emptiness and isolation on the inside" (p. 129). To ground our knowledge upon the way Dorian's character develops in the course of the novel, we could safely claim that his destiny is determined both by himself and, more importantly, by forces other than himself. Enmeshed in the heartbreaking drama, he seeks to define his hollow identity in relation to the outside world, which does not supply him with what he lacks. Thus, his destiny, dark as it is, does not offer a light to him, and, regardless of the sacrifices he readily makes to retrieve his innocence, he simply cannot change it the way he means it. In this light, the possibility of deliverance from his melancholy is not there, inciting him to submit to the fetters that are to hinder his effective movement

\section{REJOICING AT DESPONDENCY}


The outcome of Dorian's tragic life is nothing more than suffering. He comes to know that pleasure is both the basis and the reason of life. He is conscious that such a life is not as ideal as he assumes, but he goes through different stages of it to pass his malignant life. It is true that an individual may feel remorse over a sin, but he also may realize that there is not enough motive in life to remove that sin from it. Dorian Gray reaches a point in life where he only meets frustration and capriciousness. After Sybil's death, he starts to feel like a nihilist, and his nihilism assures him a kind of temporary pleasure which is to sooth his melancholy. Instead, however, it factually brings him only a perennial poignancy. Alan Carr sates that, "sadness commonly follows loss of valued objects, events, personal characteristics and skills or relationships" (2001, p. 78). Moreover, a feeling of sadness can often originate from a committed crime, as it is indicated by Dorian's pathological delicacy. The commencement of this crime determines an ill-fated ending, and it livens up his expectations only to show him the way to his doom. Indeed, such a life brings Dorian Gray closer to more sins, and deteriorates the situations which might have normally caused a call of one's conscience. Dorian's murder of Basil Hallward is a haunting memory that chases him wherever he is. Although he attempts to console himself by creating a delusional world for himself, he comes to appreciate that there is no desirable reality. What adds to the bitterness of his insufferable life is the inaccessibility to sympathy from the people around him:

"You are infamous, absolutely infamous!" he muttered.

"Hush, Alan. You have saved my life," said Dorian.

"Your life? Good heavens! What a life that is! You have gone from corruption to corruption, and now you have culminated in crime. In doing what I am going to do- what you force me to do- it is not of your life that I am thinking."

"Ah, Alan," murmured Dorian with a sigh, "I wish you had a thousandth part of the pity for me that I have for you." He turned away as he spoke and stood looking out at the garden (Wilde, p. 162).

The words and reactions of Allan Campbell, whose close friendship with Dorian later ends in bitterness, alongside the unconcern of other characters to the latter's particular situation drive him into a limbo of identity and existence. Consequently, Dorian ends up in the state of belonging to the world of non-belonging, and he realizes that the cold attention of the society is only a torturing experience which will ultimately decimate his existence.

It is then based on evidence to conclude that the suffocating and miasmatic atmosphere prevalent in the society compels people to hold dear their illusion of beauty. Under the burden of the most horrible realities, people's belief in morality and ethics is loosened or shattered, and then it is not the judgment of the society but a certain way of deliverance that matters. Living in such a situation, one futilely wishes to seek identity and tranquility in the outside world, because very quickly he gets sick and tired of his own inner strength. Kernberg (2004) puts the same idea in other words: "Self-esteem, or self regard, usually fluctuates according to whether one's relationships with others are gratifying or frustrating and according to one's evaluation of the distance between one's goals or aspirations and one's achievements" (p. 46). Dorian Gray's patience and fortitude allow him to be as strong as he can in the face of the problems of life. Yet, when his forbearance is exhausted, his reaction is not necessarily calmness and equanimity. In such a disturbance, he even frees himself from the constraints of the society to achieve the lost sense of beauty and optimism. Though, as it was discussed earlier, the reaction of the society to such a behavior is banishing the individual to the darkest pits of misery and solitariness.

In the ego process, the ego real sets the standards of proper behavior and adjustment to reality and regulates emotion. The ego ideal imparts meaning on existence and provides ideals. It consists of a collection of ideal self-representations that comprise a meaning system that, one way or the other, imposes value on the existence of self. Naturally, when the individual fails to adjust to the establishments of the ego real, he will inevitably fail to cling to the ideas as defined by the ego ideal. The morality the ego ideal prescribes struggles at this stage to penetrate into the decisions the individual makes and bases his conduct upon. The ego ideal, in this sense, seeks to establish a bridge between self and others. "The ego ideal", according to Westen (2003), "consists of values which posit an ideal relation or reconciliation of the desires of self and others" (p. 105). However, in case the ego ideal does not achieve a breakthrough, the person loses his sense of distinction and steps on the long path of self-involvement. That is to say, his impression of unwished-for realities such as a lack of care, a feeling of being outcast, and a feeling of being good-for-nothing usher him to conceive his life as a dead-end. In such circumstances, he seems to feel constrained only to adore oneself boundlessly so as to lighten the burden of non-belonging. Such a choice apparently makes life reasonable and encourages him to hope for a better future However, the danger of a helplessly hopeless self-commendation like this is that it makes one susceptible to all kinds of change. One, for instance, may react to the negative changes of his body, may become too paranoid, too pessimistic, too guilt-stricken, the danger of which is, in turn, a possible suicide. Such is the curious case of Dorian Gray. He evolves into an uncommonly delicate man. The danger of such narcissism is that it reduces him not only in the eyes of the world but even in his own. Westen argues: "The central psychological conflicts confronting the individual . . . involve the tension between (the needs and the definition of) self and others (Ibid)." He observes his guilt-stricken soul, and vainly attempts to make up for his sinful past. After his disappointment, he even becomes more amoral than before. He challenges the norms and conventions of his society through his helpless notion of self-adoration, and what ultimately remains of him is only a dead body.

Dorian Gray's predicament stresses the gravity of his psychological disturbances. A mentally healthy individual follows the line of his reason. He does not show vehement reaction to the happenings around him. Rather, he stays calm 
and does whatever he can do to put everything in the right order. Instead, by his disruptive behavior, a mentally-plagued individual only aggravates the situation for himself. Although his motive may be in setting things right, his action actually sets everything wrong. Carr (2004) postulates that, "motives to pursue particular sets of goals may be viewed as personal strengths if these motives lead to positive outcomes" (p. 191). However, in the study of Dorian's revelation we come across the downfall of a vanquished soul. Carr's claim proves that Dorian has not been successful in his quest for happiness, for he achieves nothing out of his crimes. A rumination over his own double-sided identity exposes to him the intensity of his setback for embracing his true self. If Wilde presents him as a Narcissus-like hero, it is not because he has something fascinating about him to gaze at, but because he is obliged to come up face to face with his true nature so as to observe his monstrous soul in the painting. Dorian's observation sometimes takes the form of fascination and on other occasions sheer repugnance. This duality boils down to the notion that, according to Riquelme (2011), "Dorian oscillates in a darkly narcissistic way between looking at the portrait with "loathing" and gazing "with secret pleasure, at the misshapen shadow that had to bear the burden that should have been his own" (p. 80). And after he realizes all his actions prove fruitless, he only lingers for his demise to show up at any time. The only thing that seems plausible to him is to cleave to the thought of his lost dreams to remain physically alive.

\section{CONCLUSION}

There is the peculiar representation of youth and beauty in The Picture of Dorian Gray which makes it mostly absorbing to the reader. As the study strives to show, despite Wilde's self-declared objectivity in art, the novel discusses the social maladies capable of putting an end to the sanity of individuals, and can, consequently, be viewed as his avantgarde amalgamation of aestheticism and realism. Dorian Gray comes up against his diabolical soul in a picture while he is graved in negligence and turpitude. He leads a dubious life while he seeks pleasure as the main intent of (his) life. As a result, he ultimately encounters his heart-rending destination. To him, who is fully aware of his own eccentricity, society acts as a torturing device. It does not allow him to move on communicatively in order to express his inner conflicts and his manacled individuality. Therefore, this novel is the representation of a human society in which dissimilarities are atrociously trampled on. This is to mean that Dorian's disobedience from the standard practices of his whereabouts gives rise to an impediment in his way for achieving ordinary goals. With this notion taken into consideration, we may observe that the story does not end here; rather, it marks the beginning and/or the continuation of destructive dogmas in a contaminated society where the reasons and aims of existence are construed in a unique way. The present study intends to delineate the trauma Dorian Gray grapples with in the novel as a consequence of his rejecting the norms of the society. His maniac attitude forces him into a life of cynicism which brings about nothing but a defiant identity. Dorian's soul is shackled in a way that even his conscience cannot save him from the quagmire of annihilation. He is thereby in the spotlight for breaking the social conventions and standing against the consensus on the proper lifestyle.

Dorian also attempts to rejoice at his tragedy, though not successfully. When the matter of distinction paces on the scene, it frustrates his constructive deliverance. His need of sympathy from others as well as his guilt-stricken conscience impose an unexpected forlornness upon him which is not heeded by the bystanders, and he, therefore, becomes the cause of his own destruction. Hence, the paper attempts to throw light on the dismay Dorian is gotten into, and how he helplessly struggles in bringing down the authority of frustration and misgiving. To put it in a nutshell, the study pictures the ineluctable consequences Dorian or anybody else might arrive at by standing against the unwritten laws of the society. As the novel indicates, if the society ignores such individuals, they start to lead a precarious life and break the social norms. Under the burden of isolation, these people may feel irresistible alienation, and, as they search for identity, they may cross the boundaries of the socially good and turn into law violators. In this way, they get drowned in narcissism and the mania of a 'self'.

\section{REFERENCES}

[1] Beckson, Karl. (2005). Oscar Wilde: The Critical Heritage. London: Routledge.

[2] Bloom, Harold (Ed.). (2008). Bloom's Classic Critical Views: Oscar Wilde. New York: Infobase Publishing.

[3] Carr, Alan. (2001). Abnormal Psychology. Hove: Psychology Press.

[4] Carr, Alan. (2004). Positive Psychology: The Science of Happiness and Human Strengths. Hove: Brunner-Routledge.

[5] Jenkins, Richard. (2008). Social Identity. (Third edition). London: Routledge.

[6] Kernberg, Otto F. (2004). Aggressivity, Narcissism, and Self-Destructiveness in the Psychotherapeutic Relationship. New Haven: Yale University Press.

[7] Killeen, Jarlath. (2005). The Faiths of Oscar Wilde: Catholicism, Folklore and Ireland. New York: Palgrave Macmillan.

[8] Mason, Stuart. (2011). "Oscar Wilde, Art and Morality." Retrieved from: http://www.munseys.com (Retrieved on: $8^{\text {th }}$ January, 2013).

[9] Mendelssohn, Michèle. (2007). Henry James, Oscar Wilde and Aesthetic Culture. Edinburgh: Edinburgh University Press Ltd.

[10] Rhodewart, Frederick \& Morf, Carolyn C. (2005). "Reflections in Troubled Waters: Narcissism and the Vicissitudes of an Interpersonally Contextualized Self," in On Building, Defending and Regulating the Self. Abraham Tesser et. al (Eds.). New York: Psychology Press.

[11] Riquelme, John Paul. (2011). "Oscar Wilde's Aesthetic Gothic: Walter Pater, Dark Enlightenment, and The Picture of Dorian Gray,” in Bloom's Modern Critical Views: Oscar Wilde - New Edition. Harold Bloom (Ed.). New York: Infobase Publishing. 
[12] Roden, Frederick S. (2004). Palgrave Advances in Oscar Wilde Studies. New York: Palgrave Macmillan.

[13] Schwartz-Salant, Nathan. (1982). Narcissism and Character Transformation: The Psychology of Narcissitic Character Disorders. Toronto: Inner City Books.

[14] Simon, Bernd. (2004). Identity in Modern Society: A Social Psychological Perspective. Oxford: Blackwell Publishing Ltd.

[15] Watkin, Amy. (2010). Bloom's how to Write about Oscar Wilde. Harold Bloom (Introduction). New York: Infobase Publishing.

[16] Westen, Drew. (2003). Self and Society: Narcissism, Collectivism, and the Development of Morals. Cambridge: Cambridge University Press.

[17] Wilde, Oscar. (2005). The Picture of Dorian Gray. New York: Bantam Dell.

Ali Taghizadeh is an assistant professor at the English Department of Razi University of Kermanshah, Iran, where he has taught English Language and Literature at graduate and undergraduate levels for about 16 years. He has got a B. A. in English from Shiraz University and an M. A. in English from Tehran University. The title of his M. A. thesis is "The Archetypal Theme of Expiation in Six Major Novels of Thomas Hardy and William Faulkner: A Comparative Analysis." He has also got a Ph. D. in "American Studies" from John F. Kennedy Institute for North American Studies of Free University of Berlin. The title of his doctoral dissertation is "Structuralism and Its Aftermath in the Fiction of Henry James." "Novel", "Literary Theory", "A Survey of English Literature", and "Literature in Linguistics" are among the courses which he has usually taught. In the coming semester, he will start teaching a doctoral course: "Contemporary English Fiction". The main research interests of Ali Taghizadeh are fiction, literary theory, narrative studies, and literature in language. He has translated J. Hillis Miller's On Literature into Persian, and has published some research articles both in English and in his mother tongue. He is the English editor of Narrative Studies, which is a research journal published by the Department of Persian Language and Literature of Razi University.

Mojtaba Jeihouni is a B. A. student of English Language and Literature at Razi University of Kermanshah, Iran. His main interests of research are drama and novel. He has published articles in his areas of interest in academic journals. 